\title{
Social capital in cooperatives: an evolutionary Luhmannian perspective
}

\author{
Vladislav Valentinov ${ }^{1,2}$ (D) Constantine Iliopoulos $^{3}$
}

Accepted: 10 August 2021 /Published online: 20 August 2021

(C) The Author(s) 2021

\begin{abstract}
In a recent contribution to this journal, Deng et al. (2021) draw on an extensive range of theoretical and empirical literature to make the case for the tendency of social capital resources of agricultural cooperatives in the Western world to decline over time. The present paper revisits this argument by drawing on a Luhmannian systems-theoretic perspective that takes the capitalist economic system to be limitedly sensitive and receptive to a broad variety of human needs. Whereas many of these needs remain marginalized and neglected, some of them may be codified or translated into a profit-making calculus. Cooperatives are shown to present one of the channels through which this codification may be possible; namely, the codification effect of cooperatives enables the incorporation of a multitude of mutual self-help activities into the economic system. This incorporation gives rise to intrasystemic adjustment processes that can be considered complete when the mutual self-help activities introduced by cooperatives no longer require the cooperative form and are integrated into the activities of investor-owned firms. If this view is accepted, then declining social capital may be an indicator of the successful codification process, which helps to make the economic system less exclusionary and more sensitive to human needs.
\end{abstract}

Keywords Cooperatives $\cdot$ Niklas Luhmann $\cdot$ Systems theory

JEL Classification D02 · L29 · P00

Vladislav Valentinov

valentinov@iamo.de

1 Leibniz Institute of Agricultural Development in Transition Economies, Theodor-Lieser-Str. 2, 06120 Halle, Germany

2 Department of Law and Economics, Martin Luther University, Grosse Streinstrasse 73, 06108 Halle, Germany

3 Agricultural Economics Research Institute, Terma Alkmanos Street, 11528 Athens, Greece 


\section{Introduction}

In a recent contribution to this journal, Deng et al. (2021) draw on an extensive range of theoretical and empirical literature to make the case for the tendency of social capital resources of agricultural cooperatives in the Western world to decline over time. The authors trace the indications of the declining stock of social capital along the consecutive phases of the cooperative life cycle as developed by Cook (1995). The authors rightly note that the deterioration of social capital calls for managerial responses, such as the adoption of new governance models (Deng et al. 2021). Given that many of these models are similar to the governance practices of investor-oriented firms, the decline of social capital poses a number of risks of cooperative dissolution, degeneration, and conversion into investor-owned forms of business. Minimizing these risks may call for a variety of measures for upholding and strengthening social capital among cooperative members.

Deng et al.'s (2021) argument ostensibly assumes that cooperatives and investor-owned firms exhibit a number of radical structural differences, some of which are related to the implications of social capital for organizational survival. While investor-owned forms of business are geared to promoting owners' and investors' interests, cooperatives are usefully considered to present embodiments of collective action and mutual self-help for their members (Nourse 1922; Helmberger and Hoos 1962). This means that cooperatives are user-owned and user-controlled businesses (Dunn 1988), broadly subsumable under Elinor Ostrom's (1990) notion of the commons (Tortia 2018; Beltran Tapia 2012; Marshall 2004). According to Borzaga and Tortia (2017), cooperatives are a distinct economic coordination mechanism that relies on trust and reciprocity. In various ways, these characteristics of cooperatives return to Georg Draheim's (1955) classic argument that cooperative organizations have a "double nature" combining economic and social dimensionalities.

This double nature is hardwired in cooperative routines and governance rules, enabling democratic participation and deliberation (Sacchetti and Tortia 2021). However, it follows from Deng et al.'s (2021) reasoning that these routines and rules work best when supported by sufficient social capital resources, which evidently cannot be themselves conserved therein, even though it is not uncommon for cooperatives to cultivate the development of trust among their members (SazGil et al. 2021; Kustepeli et al. 2020; Sabatini et al. 2014). While cooperatives can, in principle, generate and reinforce their own social capital (Imami et al. 2021), there are no guarantees that the social capital actually available to cooperatives will enable the smooth functioning of their routines and governance rules. If this functioning cannot be secured, cooperatives suffer from growing member heterogeneity problems (Iliopoulos and Valentinov 2018, 2017; Hoehler and Kuehl 2018) and property rights problems (Cook and Iliopoulos 2016; Iliopoulos and Theodorakopoulou 2014; Hansmann 1996) and, thus, may fail to develop effective strategies for dealing with external competitive pressures (Cook 1995). Consequently, Deng et al. (2021, p. 301) suggest that the failure of cooperatives to maintain their social capital over time may result in the disappearance of "the comparative advantage of the cooperative business form". 
Being in broad agreement with Deng et al.'s (2021) argument, the present paper embeds it in the evolutionary vision suggested by Luhmannian sociological systems theory, which helps to shift the focus away from the comparative advantage of the cooperative business form toward its wider societal ramifications. Bringing some of the contemporaneous developments in systems theory to bear on the discipline of sociology, Luhmann saw the evolution of society as a succession of the forms of social differentiation from segmentary and stratificatory to functional. To Luhmann, functional differentiation constitutes the primary distinguishing feature of modernity and denotes the decomposition of society into function systems, such as economy, law, politics, science, medicine, education, and others (cf. Roth et al. 2017). In his theory, each of these function systems employs a distinct binary code, uniquely distinguishing its operations, e.g., payment/nonpayment for the economy and government/opposition for politics. These codes are not reducible to a common denominator and thus underpin the radically heterogeneous texture of modern society (cf. Luhmann 1989, 2012). In addition to function systems, Luhmann paid considerable attention to other types of social systems, such as formal organizations. In a Luhmannian setting, agricultural cooperatives present an example of formal organizations primarily associated with the function system of the economy (cf. Iliopoulos and Valentinov 2018).

Luhmann's systems-theoretic diagnosis of the regime of functional differentiation is ambivalent. On the one hand, this regime is marked by unprecedented levels of societal complexity processed by all types of social systems. It is this complexity that enables technological advances and material well-being enjoyed by the better-positioned segments of modern society. On the other hand, Luhmann argues that the capacity of social systems to process, or codify, environmental complexity rests on their complexity-reducing function, i.e., on their tendency to disregard huge amounts of environmental complexity that go beyond their terms of reference. The systemic complexity-reducing function helps boundedly rational individuals make sense of the infinitely complex world at the cost of making the relations between social systems and their environment highly precarious. A major example of this precariousness is the ongoing ecological crisis, to which Luhmann dedicated a 1989 book. Furthermore, in virtue of their complexity-reducing function, the economic function system and corporations associated therewith are insensitive to societal and ecological occurrences that do not translate well into the code of payment/nonpayment. Relying on this code, "the economy is a rigorously closed, circular, self-referentially constituted system because it effects payments that presuppose the capacity for making payments... Thus money is a unique economic medium. It cannot be introduced as input from nor transmitted as output into the environment. Its exclusive task is to mediate system-internal operations" (ibid: 52). In accord with the spirit of contemporary ecological economics, Luhmann explained that "the key to the ecological problems, as far as the economy is concerned, resides in the language of prices... The economy cannot react to disturbances that are not expressed in this language" (Luhmann 1989: 62).

A number of Luhmannian insights have found their way into the literature on agricultural cooperatives (Iliopoulos and Valentinov 2017, 2018; Roth 2005). In these studies, agricultural cooperatives are taken to be social systems embedded in 
a potentially hostile societal environment. An interesting implication of this conceptual imagery is that the environment of cooperatives includes, among other things, cooperative members considered as whole personalities whose overall life context goes far beyond their membership in a specific cooperative. Counterintuitive as it is, this implication provides fertile ground for theorizing tensions and problems in the relationships between cooperatives and their members. Thus, in a Luhmannian setting, cooperatives may develop autonomy from, and low sensitivity to, the needs of their members, whereas the members themselves may cultivate interests and preferences that turn out to be increasingly heterogeneous. In fact, the growing autonomy of cooperatives from the needs of their members is one of the tendencies suggested by Cook's (1995) model of the cooperative life cycle, which has recently been updated and described in detail (Cook 2018). The disintegration of social capital in cooperatives is subsumed by this overall pattern.

This paper will not only explain this pattern in Luhmannian terms but also identify novel and fundamental questions potentially posed by the Luhmannian perspective about the meaning of cooperatives and cooperative social capital in a functionally differentiated society. In brief, the argument will be that the role of cooperatives crucially differs from that of investor-owned firms. Whereas the operation of the latter reflects the normal functioning of the economic function system, the former plays a key role in the evolutionary expansion of the range of this functioning. To make that case, the following sections will summarize the Luhmannian insights in the literature on agricultural cooperatives, stake out an expanded Luhmannian perspective focused on how cooperatives broaden the operational range of the economic function system, and point out some conceptual parallels related to the understanding of corporate social responsibility initiatives of investor-owned firms.

\section{Extant Luhmannian approaches}

Valentinov (2004) traced the significance of social capital for cooperatives back to Draheim's (1955) idea of the "double nature" of cooperatives. In Draheim's (1955) classic argument, cooperative organizations combine economic and social identities. Economically, a cooperative is an enterprise that must withstand competitive pressures; socially, it is a group marked by the prevalence of trust and a set of common norms and values. Iliopoulos and Valentinov (2017) revisited the notion of the cooperative double nature by drawing on the prominent debate between Luhmann and Habermas. The debate was concerned, among other things, with the relative standing and mutual relationship of the categories of system and lifeworld. From the Habermasian perspective, the system refers to "sedimented structures ... of instrumental action" (Finlayson 2005: 53), whereas the lifeworld encompasses "the stock of skills, competences, and knowledge that ordinary members of society use, in order to negotiate their way through everyday life, to interact with other people, and ultimately to create and maintain social relationships" (Edgar 2006: 89; cf. Iliopoulos and Valentinov 2017). The Habermasian normative concern, rejected by Luhmann, is that the growth of the complexity of society may have a problematic side effect of the system displacing, or "colonizing", the lifeworld (Habermas 1987). 
A key reason for the rejection of the "colonialization thesis" by Luhmann (2012) is that the latter scholar held a rather different view of the lifeworld. Instead of seeing it as "a repository of shared meanings and understandings" (Finlayson 2005: 51), Luhmann believed that lifeworlds of different individuals are unique and divergent. Assuming that the cooperative double nature essentially amounts to the cooperative sensitivity to the lifeworlds of their members, Iliopoulos and Valentinov (2017) infer from the Luhmannian theory that cooperatives present arenas of collision and conflict among the incongruent lifeworlds of members. The authors argue that the problem of member preference heterogeneity in agricultural cooperatives in the Western Hemisphere boils down to little else. Making a radical Luhmannian argument, Iliopoulos and Valentinov (2017: 1063) conclude that the double nature of cooperatives, understood as "the sensitivity of cooperatives to the lifeworld contexts of their members, exacts the price in the form of the member preference heterogeneity problem. If this sensitivity is taken to be the constitutive characteristic of cooperatives, then the proposed argument hammers home their fundamental ambivalence, as they are necessarily fraught with the potential for internal conflict". This argument clarifies why the double nature of cooperatives engenders a number of managerial dilemmas, including the "social capital dilemma" (Bijman et al. 2011). As Bijman et al. (ibid) explain, the latter dilemma means that a larger contribution of cooperatives toward coordination of the agrifood chains calls for a greater hierarchical power of professional management and, accordingly, a lesser bottom-up engagement of cooperative members.

In a further contribution, Iliopoulos and Valentinov (2018) explored the way in which the Luhmannian idea of operational closure translates into the cooperative context. According to Luhmann (2012: 32), operational closure means that social systems "produce not only their structures but also the elements of which they consist in the network of these same elements. The elements ... have no independent existence ... It is only in the system that they are produced". Accordingly, the ongoing self-reproduction of social systems involves uninterrupted succession of operational events. Furthermore, in view of the limited sensitivity of systems that are operationally closed to their environment, Luhmann assumes that these systems operate regardless of the limits of the environmental carrying capacity. The disregard for these limits is manifest in the multifarious problems of ecological and economic sustainability caused by the operation of the function system of the economy and other types of social systems. Iliopoulos and Valentinov (2018) argue that a number of problems of present-day agricultural cooperatives, such as those of member preference heterogeneity, may be understood as reflecting a peculiar disregard by cooperatives for their environmental limits.

The explanatory power of such an argument depends on the definition of the basic operation of cooperatives. Iliopoulos and Valentinov (2018) define this operation as the provision of services to members, assuming that these services correspond to members' common interests. Given that members themselves are taken to belong to the environment of cooperatives, it follows that "if cooperatives were fully sensitive to the environment, they would not expand their activity beyond the true range of common interests of the members" (ibid: 5). These common interests thus present a limit on the cooperatives' environmental carrying capacity. Cooperatives that 
operate regardless of these limits are likely to experience sustainability problems, manifested in growing member preference heterogeneity. Based on this argumentative strategy, Iliopoulos and Valentinov (2018) note the ambivalence of attempts to strengthen cooperative social capital. To the extent that these attempts seek to win the loyalty of cooperative members by the delivery of services that correspond to particular, rather than common, member interests, the heterogeneity problems and sustainability risks of cooperatives might even be aggravated. If this is the case, such attempts can be taken to present "symptomatic solutions" to member heterogeneity problems, with the fundamental solution being the ongoing "adjustment of cooperative boundaries and goals in light of the evolving range of the true common interests of members (ibid: 1 ).

\section{Toward an evolutionary Luhmannian perspective}

\subsection{The idea of codification}

Whereas the work of Iliopoulos and Valentinov $(2017,2018)$ is primarily concerned with the Luhmannian interpretations of member heterogeneity problems in cooperatives, it is clear that Luhmannian systems theory may yield even more fundamental insights both into the evolutionary role of cooperatives in the economic function system and into the functional significance of cooperative social capital. A point of departure for discerning the evolutionary role of cooperatives is Luhmann's central assumption that social systems have limited capacity to process, or codify, the complexity of their societal and natural environment. This limitation gives rise not only to sustainability risks of the concerned social systems but also to their exclusionary nature, which Luhmann saw as a key problem of the functionally differentiated society. Describing moral problems of the premodern stratified society, Luhmann drew attention to "injustice, exploitation and suppression... If, on the other hand, we see functional differentiation, our description will point to the autonomy of the function systems, to their high degree of indifference... Then we will see a society without top and without centre; a society that evolves but cannot control itself. And then, the calamity is no longer exploitation and suppression but neglect" (Luhmann 1997: 74ff.). In the case of the economic function system, the attributes of autonomy, indifference, and neglect indicate this system's limited responsiveness to societal expectations that do not translate well into the code of payment/nonpayment. These attributes may also refer to this system's exclusionary nature, which results in the lack of participation of socioeconomic groups that happen to be poor, marginalized, or otherwise disadvantaged. To appreciate the systems-theoretic significance of cooperatives in the Luhmannian framework, one needs to be aware that it is precisely these groups that are poised to benefit from cooperative mutual selfhelp activities.

To fit this observation within the Luhmannian worldview, one has to provide more concrete substance to Luhmann's argument that the codes of function systems regulate these systems' criteria of social inclusion and exclusion. While this argument per se requires no revision, it must be supplemented by an account of the 
diversity of organizational forms that are associated with the function systems. The prevalent form of organizations associated with the economic function system can be safely assumed to be the investor-owned firm, which applies the code of payment/ nonpayment along the conventional lines of profit maximization (Hansmann 1996). The economic function system, however, is home to a broad array of organizations that deviate from the ideal type of investor control. These organizations include, among others, social enterprises, cooperatives, nonprofits, and other organizations of the third sector (cf. Powell 2020). These organizations likewise apply the code of payment/nonpayment, but in a way that deviates from profit maximization. As Borzaga and Tortia (2010) explain, these organizations are oriented toward the goal of the satisfaction of needs of their key stakeholders and, thus, harness the code of payment/nonpayment to promote that goal subject to the condition of economic and financial sustainability. Thus, poor, marginalized, or otherwise disadvantaged socioeconomic groups may be largely excluded by the way investor-owned firms apply the payment/nonpayment code but may be partly brought within the ambit of this code by social enterprises, cooperatives, and other third sector organizations.

Moreover, investor-owned firms themselves may develop improved sensitivity to societal expectations. Many contemporary corporate social responsibility practices indicate the willingness of corporate managers to respond to such expectations, which are concerned not only with product prices and qualities but also with the ever widening range of moral dimensions of corporate activities (cf. Crane et al. 2019; Valentinov et al. 2019). From an evolutionary systems-theoretic point of view, these practices can be understood as the codification of some of the societal expectations on the part of corporations. This codification renders corporations more sustainable and receptive to the interests and needs of specific stakeholders. Corporate social responsibility, however, presents an initial stage of codification that is supposed to rest on the voluntary initiatives of corporate managers (cf. Crane et al. 2019). From a systems-theoretic view, codification can be taken to be complete for societal expectations for which corporate implementation is induced not by voluntary initiatives but by self-interest and profit seeking (Valentinov et al. 2019).

\subsection{The role of cooperatives}

Cooperatives are rightly believed to provide an institutional context for mutual selfhelp by actors enmeshed in a capitalist economy (e.g., Nourse 1922; Heflebower 1980; Hetherington 1991; Cook 1993; Hansmann 1996). Mutual self-help activities have to be undertaken by cooperatives because the profit-driven capitalist economy is limitedly responsive to, or fails to codify, a specific range of common interests of cooperative members. Had the creation of cooperatives been impossible, these interests would have remained unrealized. In a sense, cooperatives present local contexts where the code of payment/nonpayment becomes less restrictive and exclusionary in specific ways that, in a more familiar terminology, are known as the economic justifications of cooperatives. These justifications include correcting for market failures, reducing the gap between producer prices and consumer prices, influencing consumer prices, reducing farmer-member risk, providing missing services, reducing 
asymmetric information, providing individual producers with market access, utilizing scale and/or scope economies, and improving supply chain coordination (Nourse 1922; Sapiro 1923; Sexton and Iskow 1988; Cook 1993; Hansmann 1996). From a systems-theoretic view, all of these economic justifications present specific channels through which the economic function system gains enhanced sensitivity to specific needs and interests that are not easily translated into the code of payment/nonpayment. This sensitivity remains local and does not affect the overall exclusionary nature of the code, as exemplified in the operation of the prevalent investor-owned firms.

Thus, the idea of codification highlights a systems-theoretic distinction between the functions of cooperatives and investor-owned firms. In a Luhmannian view, the operation of cooperatives reflects the economic system's efforts to codify a range of economic needs and interests that are too marginal to qualify for inclusion in this system's regular operation. In contrast, investor-owned firms reflect this very operation. Given the evolutionary drive of the economic system to incorporate an ever broader range of activities, cooperatives fulfill the function of pioneers who carry out the task of integrating novel environmental signals into the economy. The arguments known as "the economic justifications" of cooperatives illuminate the conditions of this task's feasibility. To be sure, cooperatives are not the only institutions of this type and have a number of functional equivalents, one of which is corporate social responsibility, which likewise reflects the efforts of corporate managers to take into account novel environmental signals. Other examples include a range of social enterprises and third sector organizations aimed at promoting economic inclusion, e.g., through social innovation (e.g., Tortia et al. 2020). However, from a Luhmannian view, all these functional equivalents are properly thought of as the initial stage of codification. Codification is finalized when the novel environmental signals stop being novel and are fully processed within the regular operation of price mechanism, self-interest, and profit-seeking calculus.

"Full processing of environmental signals within the regular operation of price mechanism", as understood here, generalizes the notion of the so-called "competitive yardstick' role identified by Nourse (1922) for agricultural cooperatives. Nourse (ibid) argued that agricultural cooperatives should exit as soon as they have corrected for the market failure that challenged their farmer members. The world history of agricultural cooperatives provides plenty of case studies and anecdotal evidence concerning successful cooperatives that transformed into investor-oriented firms after their yardstick role was accomplished. Recent examples include Diamond Walnut Growers, Dakota Growers Pasta Company, PRO-FAC Cooperative, Rice Growers Association in the U.S.A. (Fulton and Hueth 2009), ForFarmers in the Netherlands (Cook and Iliopoulos 2016), and Westralian Farmers Co-operative in Australia (Cheong 2006).

A Luhmannian systems-theoretic view suggests, however, that the yardstick effect has a broader societal role consisting of (locally) enhancing the inclusiveness of the economic function system's code of payment/nonpayment. By disallowing the goal of profit maximization, cooperatives bring within the ambit of this code new activities that would have remained unrealized otherwise. Once these activities are brought in, the economic function system undergoes adjustment processes, 
which may take the form of the yardstick effect (Liang and Wang 2020; Liang and Hendrikse 2016; Sexton 1990) or other positive external effects, such as the promotion of trust and social capital (Saz-Gil et al. 2021; Kustepeli et al. 2020; Sabatini et al. 2014). In the Luhmannian view, the local enhancements of inclusiveness of the payment/nonpayment code do not require these effects to be large-scale, pervasive, or game-changing in any way. The economic significance of cooperatives, according to this perspective, does not need to be any less marginal than the economic significance of the human needs it addresses. Moreover, somewhat ironically, the emergence of property rights problems and member heterogeneity problems in wellestablished cooperatives may even be taken as evidence of the codification process being well along the way.

The latter point underscores the ambivalence of cooperative social capital. On the one hand, it is clear that the economic justifications of cooperatives work to the extent that cooperative members can draw on mutual trust, common values, and other social capital components (e.g., Svendsen and Svendsen 2004). As Deng et al. (2021) aptly note, social capital helps cooperatives emerge and is thus critically important for nudging the economic system toward discovering new horizons of environmental complexity. On the other hand, once cooperatives have got off the ground and started new mutual self-help activities, the full codification of these activities into the regular operation of price mechanisms and profit-seeking calculus calls for their decoupling from human and interpersonal relations. To Luhmann, this decoupling constitutes a key ingredient of the autonomous and self-steering nature of the economic function system and other types of social systems. A high degree of social capital dependence on cooperative activities may, accordingly, hinder the successive incorporation of the original mutual self-help activities into the regular operation of the economic system.

This characterization of the role of social capital may be quite counterintuitive for cooperative scholars who consider the double nature to be not only a distinguishing characteristic of cooperatives but also a foundation for their competitive advantage (Bonus 1986; Nilsson et al. 2012). Member heterogeneity problems, addressed by Iliopoulos and Valentinov $(2017 ; 2018)$ and others (e.g., Iliopoulos and Cook 1999; Hoehler and Kuehl 2018), can be likewise interpreted as tensions induced by the growing need for the autonomy of those economic activities that used to be enmeshed in dense webs of interpersonal relations. The problematic nature of member heterogeneity and of declining social capital for cooperatives can thus be discerned from two opposite perspectives. From the perspective apparently shared by the bulk of the cooperative literature, these problems are emblematic of the difficulties experienced by cooperatives that have to compete against large and powerful investor-owned firms. From the evolutionary systems-theoretic perspective advanced here, these problems are frictions on the way toward the full incorporation of cooperative activities into the regular operation of the economic function system.

Paradoxically, however, this incorporation requires that cooperatives are given full opportunity to practice distinct behaviors that are uniquely different from those of investor-owned firms because this difference gives a boost to the adjustment processes in the economic function system. For example, worker cooperatives tend to offer higher employment stability and to generate higher worker satisfaction than 
comparable investor-owned firms (Albanese et al. 2019; Borzaga and Tortia 2006). Cooperatives have proven to be more resilient in times of economic crises than investor-owned firms (Birchall and Ketilson 2009); this is especially true for cooperative banks (Henselmann et al. 2016). Agricultural cooperatives in many countries pay higher product prices or charge lower farm input prices to their farmer members than competing investor-owned firms (Bijman et al. 2012). The competitive yardstick effects emerging from these practices force investor-owned firms, which compete for the patronage of local farmers, to pay similar price and/or improve the services they offer to farmers (e.g., Liang and Hendrikse 2016). From the systemstheoretic view, these yardstick effects are part of the codification process, which is facilitated by the diversity of possible applications of the economic function system code of payment/nonpayment.

\subsection{Revisiting the functional equivalence between cooperatives and corporate social responsibility}

The suggested systems-theoretic view of the functional equivalence between cooperative activities and corporate social responsibility practices implies important commonalities and differences between them. The key commonality can be traced back to Draheim's (1955) idea of the double nature of cooperatives, broadly understood as a combination of economic and social dimensions. Contrary to Draheim's view of the double nature as a distinguishing characteristic of cooperatives, this idea appears to have counterparts in the context of investor-owned firms. First, business ethics and management scholars have long been engaged in the debate on the proper goals of the firm. While the mainstream view has been that firms must engage in longrun profit maximization (cf. Friedman 1970), today's turbulent and unpredictable business environment often induces them to pay attention to stakeholder interests, to promote sustainability, and to assume political responsibilities (Pies et al. 2021), thereby creating "social value" (Hall et al. 2015) or "collective value" (Donaldson and Walsh 2015). The phenomenon of corporate social responsibility can itself be justified on ethical or instrumental grounds, the mutual relationship of which continues to be debated (Crane et al. 2019). Even though these types of debates are far from resolved, they show that the autonomy of investor-owned firms is by no means absolute. Many of these firms are under pressure to secure their sustainability and legitimacy by becoming more responsive to their environment, societal and ecological alike.

While corporate social responsibility may present a channel for improving corporate responsiveness to societal expectations, this channel's effectiveness is lowered by the phenomenon of corporate hypocrisy (Wagner et al. 2009), which includes several varieties, such as greenwashing (e.g., de Freitas Netto et al. 2020) and bluewashing (e.g., Berliner and Prakash 2015). Corporate hypocrisy means that corporations pursue their corporate social responsibility policies in a symbolic and strategic way to gain reputational advantages (Cho et al. 2015). Jauernig and Valentinov (2019) argue, however, that corporate hypocrisy cannot fully undermine the idea of corporate social responsibility. To the extent corporate hypocrisy is discerned by 
corporate stakeholders, it generates skeptical attitudes, which corporations can only counter by delivering on at least some of the promises and claims they make in the course of their communication and public relations campaigns (ibid). This argument is reinforced by Christensen et al.'s (2013) idea that corporate social responsibility communication may present "aspirational talk" that effectively commits and induces corporations to fulfil their claims, even if this fulfilment is never perfect. Corporations thus remain able to remain responsive to the societal environment both through their real corporate social responsibility policies and through "aspirational talk" (ibid).

The key difference between cooperatives and investor-owned firms concerns the evolutionary status of this responsiveness. As Deng et al. (2021) suggest, the evolutionary trajectory of the cooperative life cycle involves a shift from the initial responsiveness to member needs toward growing member heterogeneity problems, some of which can be addressed by adopting governance models quite similar to those of investor-owned firms. However, many of these firms are themselves subject to evolutionary forces that make them more responsive to their societal environment. Thus, from a Luhmannian point of view, it is possible to conceptualize a balance between the autonomy of social systems and their responsiveness to the environment (Valentinov 2014). Cooperatives and investor-owned firms can seek this balance, taking different evolutionary paths. For the former, the path is from greater responsiveness to greater autonomy; for the latter, the path tends to be opposite. In various institutional contexts, these paths may become similar to each other, but they do not need to converge. In fact, their nonconvergence is at the heart of the diversity of the applications of the economic function system code of payment/nonpayment, given that this diversity is a crucial facilitator of the codification process.

Many debates on the corporate social responsibility of investor-owned firms are controversial because of the lack of consensus on fundamental philosophical paradigms. One such controversy centers on the relative moral roles of institutions and individuals in modern society (Pies et al. 2021). The paradigm of institutional ethics takes institutions to be the primary repositories of morality, whereas that of individual ethics assumes morality to depend on the virtuous or sinful behavior of individuals (ibid; Heath 2014). Drawing inspiration from the Smithian idea of the invisible hand, the institutional ethics paradigm pleads for institutional reforms aimed at alleviating individual moral burdens by codifying moral projects into the rational pursuit of self-interest. Iliopoulos and Valentinov (2017) draw on these two paradigms to make sense of member heterogeneity problems in cooperatives. According to the authors, attempts to deal with these problems by strengthening individual member loyalty and commitment would correspond to the individual ethics paradigm, while the institutional ethics paradigm would rather endorse adopting innovative governance models. The systems-theoretic idea of codification aimed at expanding the range of the economic function system evidently falls in line with the latter paradigm, especially if the new governance structures resemble those from the forprofit sector. However, this paradigm rests on the implicit assumption of the sustainability of institutions which may be infused with moral significance. If the role of cooperatives is to merely broaden the range of the regular operation of the economy, then, for any specific set of mutual self-help activities, this role is transient. If the 
institutional ethics paradigm holds, it holds for the institutions of the for-profit sector rather than for cooperatives.

\section{Conclusions}

The key contribution of the present paper is to revisit Deng et al.'s (2021) comprehensive account of the decline of social capital throughout the life cycle of agricultural cooperatives by drawing on a Luhmannian systems-theoretic perspective. In the Luhmannian view, the operations of the economic function system are framed by the code of payment/nonpayment; as a result, this system is limitedly sensitive and receptive to a broad variety of human needs. Those needs that do not translate well into this code have a lower chance of appearing on this system's radar and, thus, of being codified by, or included in, the economic system. However, the code of payment/nonpayment admits a variety of specifications that may vary according to specific types of organizations affiliated with the economic function system. These specifications present alternative and complementary channels through which codification may be possible. While investor-owned firms constitute the dominant channel of codification, cooperatives present another channel that applies the code of payment/nonpayment in ways that differ from the practices of investor-owned firms. The emerging codification effect of cooperatives enables incorporation into the economy of a multitude of mutual self-help activities. This incorporation gives rise to intrasystemic adjustment processes, which are well described in the case of agricultural cooperatives by the notion of the competitive yardstick (Nourse 1922; Liang and Wang 2020; Liang and Hendrikse 2016; Sexton 1990). One implication of this argument is that the possibility of the codification and concomitant adjustment processes crucially rests on the diversity of possible specifications and applications of the payment/nonpayment code. Another implication is that the codification of the mutual self-help activities introduced by cooperatives is complete when these activities no longer require the cooperative form and are integrated into the capitalist for-profit calculus.

As Deng et al. (2021) suggest, the availability of social capital in the initial stages of the life cycle is essential to help cooperatives get off the ground. The authors' discernment of declining social capital may, however, reflect the progress of the codification of new mutual self-help activities into the economic function system and thus may not need to be regarded as deeply problematic from a systems-theoretic view. This perspective thus delineates two major areas of further research, both positive and normative. In positive terms, more efforts are needed to gauge the empirical extent to which the codification of novel activities is proceeding in such a way as to make the economic system less restrictive and exclusionary. If the economic system indeed becomes less exclusionary, then new normative arguments are needed to reach greater clarity on whether the social capital resources of cooperatives ought to be deliberately maintained.

Acknowledgements The authors are grateful to anonymous reviewers for their very helpful comments. 
Funding Open Access funding enabled and organized by Projekt DEAL.

\section{Declarations}

Conflict of interest There is no conflict of interest.

Open Access This article is licensed under a Creative Commons Attribution 4.0 International License, which permits use, sharing, adaptation, distribution and reproduction in any medium or format, as long as you give appropriate credit to the original author(s) and the source, provide a link to the Creative Commons licence, and indicate if changes were made. The images or other third party material in this article are included in the article's Creative Commons licence, unless indicated otherwise in a credit line to the material. If material is not included in the article's Creative Commons licence and your intended use is not permitted by statutory regulation or exceeds the permitted use, you will need to obtain permission directly from the copyright holder. To view a copy of this licence, visit http://creativecommons.org/licen ses/by/4.0/.

\section{References}

Albanese M, Navarra C, Tortia E (2019) Equilibrium unemployment as a worker insurance device: wage setting in worker owned enterprises. Economia Politica 36(3):653-671

Beltran Tapia FJ (2012) Commons, social capital, and the emergence of agricultural cooperatives in early twentieth century Spain. Eur Rev Econ Hist 16:511-528

Berliner D, Prakash A (2015) "Bluewashing" the firm? Voluntary regulations, program design, and member compliance with the United Nations Global Compact. Policy Stud J 43(1):115-138

Bijman J, Muradian R, Cechin AD (2011) Agricultural cooperatives and value chain coordination”. In: Helmsing AHJ, Vellema S (eds) Value chains, inclusion and endogenous development: Contrasting theories and realities. Routledge, Oxford, pp 82-101

Bijman J, Iliopoulos C, Poppe K, Gijselinckx C, Hagedorn K, Hanisch M, Hendrikse G, Kühl R, Ollila P, Pyykkönen P, Van der Sangen G (2012) Support for farmers' cooperatives. Final report. November 2012, Wageningen UR, Wageningen, the Netherlands.

Birchall J, Ketilson LH (2009) Resilience of the cooperative business model in times of economic crisis. Technical Report, ILO, Geneva, Switzerland, https://www.ilo.org/wcmsp5/groups/public/---ed_ emp/emp_ent/documents/publication/wcms_108416.pdf.

Bonus $\mathrm{H}$ (1986) The cooperative association as a business enterprise: a study in the economics of transactions. J Inst Theor Econ 142:310-339

Borzaga C, Tortia E (2010) The economics of social enterprises: An interpretive framework. In: Becchetti L, Borzaga C (Eds) The economics of social responsibility: The world of social enterprises. Routledge, pp. 15-33.

Borzaga C, Tortia E (2006) Worker motivations, job satisfaction, and loyalty in public and non-profit social services. Nonprofit Volunt Sect Q 35(2):225-248

Borzaga C, Tortia E (2017) Cooperation as coordination mechanism: A new approach to the economics of cooperative enterprises. In: Mitchie J, Blasi J, Borzaga C (eds) The Oxford Handbook of Mutual, Cooperative, and Co-owned Business. Oxford University Press, Oxford, pp 55-75

Cheong E (2006) The agricultural co-operative business structure in context: A Western Australian Study. PhD Dissertation, Edith Cowan University, Australia; https://ro.ecu.edu.au/theses/56.

Cho CH, Laine M, Roberts RW, Rodrigue M (2015) Organized hypocrisy, organizational façades, and sustainability reporting. Acc Organ Soc 40:78-94

Christensen LT, Morsing M, Thyssen O (2013) CSR as aspirational talk. Organization 20(3):372-393

Cook ML (1995) The future of US agricultural cooperatives: A neo-institutional approach. Am J Agr Econ 77(5):1153-1159

Cook ML, Iliopoulos C (2016) Generic solutions to coordination and organizational costs: Informing cooperative longevity. Journal on Chain and Network Science 16(1):19-27

Cook ML (1993) "Cooperatives and Group Action.” In: Padberg D (ed) Food and agricultural marketing issues for the 21st century. Texas A\&M University, FAMC 93-1, pp. 154-169. 
Cook ML (2018) A life cycle explanation of cooperative longevity. Sustainability 10(5), article No. 1586; https://doi.org/10.3390/su10051586.

Crane A, Matten D, Glozer S, Spence LJ (2019) Business ethics: Managing corporate citizenship and sustainability in the age of globalization. Oxford University Press, Oxford et al

de Freitas Netto SV, Sobral MFF, Ribeiro ARB, da Luz Soares GR (2020) Concepts and forms of greenwashing: a systematic review. Environ Sci Eur 32:1-12

Deng W, Hendrikse G, Liang Q (2021) Internal social capital and the life cycle of agricultural cooperatives. J Evol Econ 31(1):301-323

Donaldson T, Walsh JP (2015) Toward a theory of business. Research in Organizational Behavior 35:181-207

Draheim G (1955) Die Genossenschaft als Unternehmungstyp. Vandenhoeck \& Ruprecht, Goettingen, Germany

Dunn JR (1988) Basic cooperative principles and their relationship to selected practices. J Agric Coop 3:83-93

Edgar A (2006) Habermas: The key concepts. Routledge, London

Finlayson JG (2005) Habermas: A very short introduction. Oxford University Press, Oxford, UK

Friedman M (1970) The social responsibility of business is to increase its profits. New York Times, September 13, 33 .

Fulton M, Hueth B (2009) Cooperative conversions, failures and restructurings: Case studies and lessons from U.S. and Canadian agriculture. Centre for the Study of Co-operatives, University of Saskatchewan, Saskatoon, Canada.

Habermas J (1987) The Theory of Communicative Action, Volume 2: Lifeworld and System: A Critique of Functionalist Reason. Beacon Press, Boston.

Hall M, Millo Y, Barman E (2015) Who and what really counts? Stakeholder prioritization and accounting for social value. J Manage Stud 52(7):907-934

Hansmann H (1996a) The Ownership of Enterprise. The Belknap Press of Harvard University Press, Cambridge, MA, USA

Heath J (2014) Morality, Competition, and the Firm: The Market Failures Approach to Business Ethics. Oxford University Press, Oxford et al

Heflebower RB (1980) Cooperatives and Mutuals in the Market System. The University of Wisconsin Press, Madison

Helmberger P, Hoos S (1962) Cooperative enterprise and organization theory. Journal of Farm Economics 44(2):275-290

Henselmann K, Ditter D, Lupp P (2016) The effects of the financial crisis on cooperative banks in europe - A critical comparison. Working Papers in Accounting Valuation Auditing, No. 2016-1, FriedrichAlexander-Universität Erlangen- Nürnberg, Lehrstuhl für Rechnungswesen und Prüfungswesen, Nürnberg, Germany, https://www.econstor.eu/bitstream/10419/161671/1/WP\%202016-1\%20Effects\% 20of\%20Financial\%20Crisis\%20on\%20Cooperative\%20Banks.pdf.

Hetherington JAC (1991) Mutual and Cooperative Enterprises: An Analysis of Customer-owned Firms in the United States. University Press of Virginia, Charlottesville and London

Hoehler J, Kuehl R (2018) Dimensions of member heterogeneity in cooperatives and their impact on organization-a literature review. Annals of Public and Cooperative Economics 89(4):697-712

Iliopoulos C, Cook ML (1999) The efficiency of internal capital markets in customer-owned firms: The influence costs problem. $3^{\text {rd }}$ Annual Conference of the International Society for New Institutional Economics, Washington D.C., USA, September 16-18, 1999.

Iliopoulos C, Valentinov V (2018) Member heterogeneity in agricultural cooperatives: A systems-theoretic perspective. Sustainability, 10(4), article No. 1271.

Iliopoulos C, Theodorakopoulou I (2014) Mandatory cooperatives and the free rider problem: The case of Santo Wines in Santorini, Greece. Annals of Public and Cooperative Economics 85(4):63-681

Iliopoulos C, Valentinov V (2017) Member preference heterogeneity and system-lifeworld dichotomy in cooperatives. J Organ Chang Manag 30(7):1063-1080

Imami D, Valentinov V, Skreli E (2021) Food safety and value chain coordination in the context of a transition economy: The role of agricultural cooperatives. Int J Commons 15(1):21-34

Jauernig J, Valentinov V (2019) CSR as hypocrisy avoidance: a conceptual framework. Sustainability Accounting, Management and Policy Journal 10(1):2-25

Kustepeli Y, Gulcan Y, Yercan M, Yildirim B (2020) The role of agricultural development cooperatives in establishing social capital. Annals of Regional Science, Advance Online Publication,. https://doi.org/ 10.1007/s00168-019-00965-4 
Liang Q, Wang X (2020) Cooperatives as competitive yardstick in the hog industry?-Evidence from China. Agribusiness: An International Journal 36: 127-145.

Liang Q, Hendrikse G (2016) Pooling and the yardstick effect of cooperatives. Agric Syst 143:97-105

Luhmann N (1989a) Ecological Communication. The University of Chicago Press, Chicago

Luhmann N (1997) Globalization or world society: how to conceive of modern society? Int Rev Sociol 7(1):67-79

Luhmann N (2012) Theory of Society, vol 1. Stanford University Press, Stanford

Marshall GR (2004) Farmers cooperating in the commons? A study of collective action in salinity management. Ecol Econ 51:271-286

Nilsson J, Svendsen GL, Svendsen GT (2012) Are large and complex agricultural cooperatives losing their social capital? Agribusiness 28(2):187-204

Nourse EG (1922) The economic philosophy of co-operation. Am Econ Rev 12(4):577-597

Ostrom E (1990) Governing the Commons. Cambridge University Press, Cambridge

Pies I, Schreck P, Homann K (2021) Single-objective versus multi-objective theories of the firm: using a constitutional perspective to resolve an old debate. Rev Manag Sci 15(3):779-811

Powell WW (2020) What is the nonprofit sector? In: Powell WW, Bromley P (eds) The nonprofit sector: a research handbook, 3rd edn. Stanford University Press, Stanford, pp 3-18

Roth S, Clark C, Trofimov N, Mkrtichyan A, Heidingsfelder M, Appignanesi L, Kaivo-Oja J (2017) Futures of a distributed memory. A global brain wave measurement (1800-2000). Technol Forecast Soc Chang 118:307-323

Roth S (2005) Rinder - Genossen - Exportweltmeister: Zur Evolution einer „strukturellen Kopplung“. In Aderhold J, Rosenberger M, Wetzel R (Eds), Modernes Netzwerkmanagement: Anforderungen Methoden - Anwendungsfelder. Springer Gabler, Wiesbaden.

Sabatini F, Modena F, Tortia E (2014) Do cooperative enterprises create social trust? Small Bus Econ 42:621-641

Sacchetti S, Tortia E (2021) Governing cooperatives in the context of individual motives. Int J Soc Econ 48(2):181-203

Sapiro A (1923) True farmer cooperation. World's Work, May 1923: 84-96.

Saz-Gil I, Bretos I, Díaz-Foncea M (2021) Cooperatives and social capital: A narrative literature review and directions for future research. Sustainability 13, article \# 534.

Sexton RJ (1990) Imperfect competition in agricultural markets and the role of cooperatives: A spatial analysis. Am J Agr Econ 72(3):709-720

Sexton R, Iskow J (1988). Factors Critical to the Success or Failure of Emerging Agricultural Cooperatives. Giannini Foundation Information Series No. 88-3, University of California-Davis: Oakland, CA.

Svendsen GLH, Svendsen GT (2004) The creation and destruction of social capital: Entrepreneurship, cooperative movements and institutions. Edward Elgar, Cheltenham, UK

Tortia EC, Degavre F, Poledrini S (2020) Why are social enterprises good candidates for social innovation? Annals of Public and Cooperative Economics, advance online publication, Looking for personal and institutional drivers of innovation. https://doi.org/10.1111/apce.12265

Tortia EC (2018) The firm as a common. Non-divided ownership, patrimonial stability and longevity of cooperative enterprises. Sustainability 10 (4), Article \#1023.

Valentinov V (2004) Toward a social capital theory of cooperative organisation. Journal of Cooperative Studies 37(3):5-20

Valentinov V (2014) The complexity-sustainability trade-off in Niklas Luhmann's social systems theory. Syst Res Behav Sci 31(1):14-22

Valentinov V, Roth S, Will MG (2019) Stakeholder theory: A Luhmannian perspective. Administration and Society 51(5):826-849

Wagner T, Lutz RJ, Weitz BA (2009) Corporate hypocrisy: Overcoming the threat of inconsistent corporate social responsibility perceptions. J Mark 73(6):77-91

Publisher's note Springer Nature remains neutral with regard to jurisdictional claims in published maps and institutional affiliations. 